О.О. Корольов ${ }^{1}$, І.М. Сила ${ }^{1}$, О.І. Сиза ${ }^{2}$, В.В. Гейко ${ }^{1}$

${ }^{1}$ Держсавний науково-дослідний інститут випробувань $і$ сертифікаиії озброєння та військової техніки, Чернігів

${ }^{2}$ Національний Університет “Чернігівський колегіум” ім. Т.Г. Шевченка, Чернігів

\title{
ЕКСПЕРИМЕНТАЛЬНЕ ВИЗНАЧЕННЯ СТАНУ МАТЕРІАЛІВ ПАРАШУТНОЇ СИСТЕМИ Д-5 СЕРІЇ 2. СТАТИСТИЧНІ ХАРАКТЕРИСТИКИ МІЦНОСТІ ТКАНИНИ ОСНОВНОГО ПАРАШУТУ
}

\begin{abstract}
Предметом вивчення в статті є аналіз масиву експериментальних даних навантаження при розриві тканини по основі куполу парашуту основного десантних парашутних систем Д-5 серій 21973 та 1974 років виготовлення після їх тривалого зберігання з нульовим (невичерпаним) ресурсом. Метою статті є спроба на основі статистичного аналізу результатів вимірювань визначити співвідношення впливу зовнішніх чинників, пов'язаних з природними факторами старіння полімерів та умовами зберігання, і внутрішніх, щзо обумовлені похибками в процесі вимірювання. Завдання: визначити оптимальний перелік даних статистичного аналізу результатів вимірювання для оцінки якості процесу вимірювання. Використовувалися наступні методи і устаткування. Вдосконалена методика відбору точкових проб досліджуваних зразків десантних парашутних систем Д-5 серій 2 для проведення лабораторних досліджень за визначенням навантаження при розриві тканини куполу парашуту основного. Вимірювання проводились на машині розривній марки ИР 5047-50М2С, клас точності - 0,5 для діапазону вимірювань від 0,5 кН до 5 кН. Об'єм партії склав 25 парашутних систем, всього 250 елементарних проб. Масив емпіричних даних був оброблений математикостатистичними методами пакету програм Описова статистика з надбудови Пакету Аналізу MS EXCEL. Отримані наступні результати. Відносна похибка результатів вимірювання навантаження при розриві тканини по основі куполів парашутів 1973 року виготовлення склала $\pm 3,9 \%$, для парашутів 1974 року виготовлення - $\pm 6,8 \%$ \% 3 урахуванням того, щзо прилад для вимірювання має похибку $\pm 0,29 \%$ за паспортом, яку можна вважати систематичною, загальний рівень невизначеності є прийнятним для звичайних вимірювань у техніці. Висновки. Основними чинниками появи випадкових похибок у прочесі вимірювання навантаження при розриві тканини куполу по основі парашуту основного є внутрішні фактори, обумовлені організацією та проведенням вимірювань.
\end{abstract}

Ключові слова: тканина, статистика, аналіз, парашут.

\section{Вступ}

Постановка проблеми. Успішність виконання операцій Десантно-штурмових військ і Сил спеціальних операцій багато в чому залежить від стану озброєння і військової (спеціальної) техніки, в тому числі і від парашутної техніки, яка експлуатується або знаходиться на зберіганні у військових частинах. Продовження строку дії призначених показників людських парашутних систем вимагає проведення періодичних лабораторних і льотних випробувань. Якісне матеріальне і методичне забезпечення проведення таких робіт $€$ передумовою для оцінки стану парашутної системи.

Міцність тканини куполу основного парашута $\epsilon$ одним з ключових елементів успішного застосування парашутної системи у цілому. Окрім визначення фактичного значення фізичних характеристик тканини і оцінці самого процесу вимірювання актуальною $є$ задача визначення величини вибірки парашутів із загальної їх кількості при подальших роботах по продовженню строку дії призначених показників [1]. На величину мінімальної необхідної вибірки впливає величина генеральної вибірки, бажана гранична похибка та дисперсія, обчислена за результатами вимірювання. Отримані статистичні характеристики будуть основою при плануванні аналогічних досліджень у майбутньому.

Представлені дослідження є частиною комплексної науково-дослідної роботи на виконання Рішення № 1/ПДТ - 2020 про організацію досліджень (робіт) щодо продовження (збільшення) строку дії призначених (встановлених) показників повітрянодесантної техніки Збройних Сил України, яке затверджене профільним заступником Міністра оборони України 31.07.2020 (шифр робіт: "Показник2020") [2].

Аналіз останніх досліджень і публікацій. Найбільш відомі роботи теоретичного і практичного спрямування виконані фахівцями Національного аерокосмічного університету ім. Н.С. Жуковского 
“ХАI”, Харків, Україна [3-6]. Наприклад, у роботі [5] було доведене справедливість нормального закону розподілу руйнівних навантажень для строп i тканини куполу як по основі, так і по утоку. Зроблений висновок про стабільність запропонованої методики випробувань і якість розроблених пристосувань для випробувань.

У повідомленні 1 [7] були представлені основні методичні засади та результати експериментів по визначенню розривного навантаження тканини куполу основного парашуту. Основною метою тоді було визначення ступеня деградації полімерних матеріалів, яке показало, що навантаження при розриві тканини куполу основного парашуту по основі і по утоку знаходиться на межі нормативного значення за вимогами ГОСТ 13090-90, але оцінка якості вимірювань не проводилась.

У якості метода розрахунків максимального навантаження на тканину куполу парашута відомий підхід, запропонований Н.А. Лобановим [8], який встановлює, що напруження $\sigma_{\text {верт }}$ у вертикальному перерізі у 1,57 разів більше за напруження $\sigma_{\text {гор }}$ у горизонтальному перерізі куполу парашуту. В вертикальному перерізі розташовані нитки основи тканини, тому у цій роботі ми цілком виправдано обмежились дослідженнями статистичних характеристик результатів вимірювань навантаження при розриві тканини куполу по основі.

Відомі спроби застосувати методи математичної статистики [9] у визначенні нормативних значень показників міцності тканини, як одного з показників якості [10].

Мета статті - $\epsilon$ спроба на основі статистичного аналізу результатів вимірювань визначити співвідношення впливу зовнішніх чинників, пов'язаних 3 природними факторами старіння полімерів, і внутрішніх, що обумовлені похибками в процесі вимірювання.

\section{Виклад основного матеріалу}

Об'єктом лабораторних досліджень була тканина куполу основного парашуту десантних парашутних систем Д-5 серії 21973 та 1974 року виготовлення, після їх тривалого зберігання, з нульовим (невичерпаним) ресурсом. Величина партії становила 25 комплектів парашутних систем. Тканина куполу основного парашуту має артикул 56009П за ГОСТ 13090-90, поверхнева щільність тканини не більше $58 \mathrm{\Gamma} / \mathrm{m}^{2}$, номінальне значення розривного навантаження смуги тканини розміром 50х200 мм по основі не менше 49,0 даН, по утоку - не менше 47,0 даН.

Вимірювання навантаження при розриві елементарних проб тканини основного парашуту проводили не менше 10 разів в однакових умовах за по- ложеннями Методики № 1 лабораторних випробувань по визначенню механічних характеристик текстильних матеріалів, які застосовані при виготовленні десантної парашутної системи Д-5 серії 2.

Використовувалась машина розривна марки ИР 5047-50М2С, клас точності - 0,5 для діапазону вимірювань від 0,5 кН до 5 кН, похибка вимірювання (відтворення) - 0,29\%.

Елементарні проби (експериментальні зразки) перед дослідженнями були витримані на протязі 24 годин у вільному стані в нормальних кліматичних умовах: температура повітря $20^{\circ} \mathrm{C} \pm 2{ }^{\circ} \mathrm{C}$, відносна вологість повітря $65 \% \pm 2 \%$ [2].

Чисельні значення результатів вимірювання для кожного зразка оброблялись апаратурним комплексом розривної машини та фіксувались на моніTopi.

Масив емпіричних даних за результатами 250 вимірів був оброблений математико-статистичними методами пакету програм. Описова статистика, що входить в надбудову Пакету Аналізу MS EXCEL. Розраховували показники вибірки: середнє, медіана, дисперсія, ексцес, невизначеність (похибка) з вірогідністю 0,95 .

При проведенні робіт [2] були досліджені дві групи парашутних систем 1973 та 1974 років виготовлення, які зберігалися у різних військових частинах. За результатами статистичної обробки експериментальних даних вимірювання навантаження при розриві тканини куполу основного парашуту побудовані криві розподілу густини ймовірності для кожної вибірки. Криві розподілу ймовірності мають характерний для нормального розподілу вигляд та наведені для парашутів 1973 року виготовлення на рис. 1 і для парашутів 1974 року виготовлення на рис. 2 .

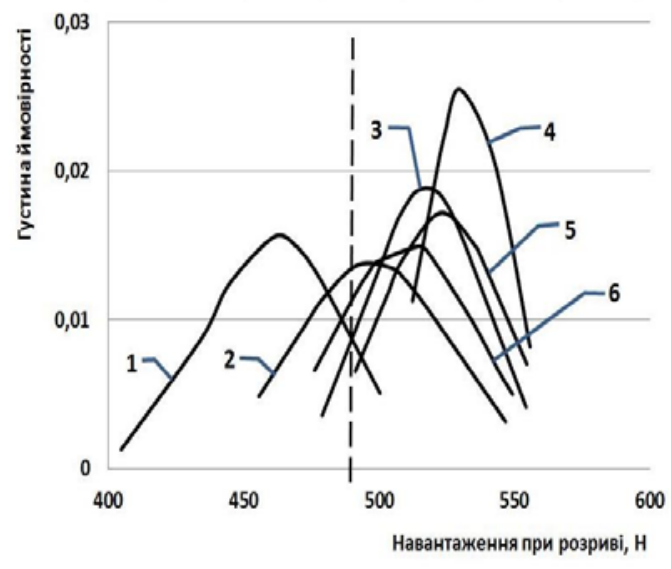

Рис. 1. Графік залежності густини ймовірності від навантаження при розриві по основі тканини куполу парашута основного (1973 рік виготовлення): 1 - № 7329301; 2 - № 7329215; 3 - № 7317206; 4 - № 7320301; 5 - № 7320110; 6 - № 7306722 . Джерело: розроблено авторами за даними [2]. 


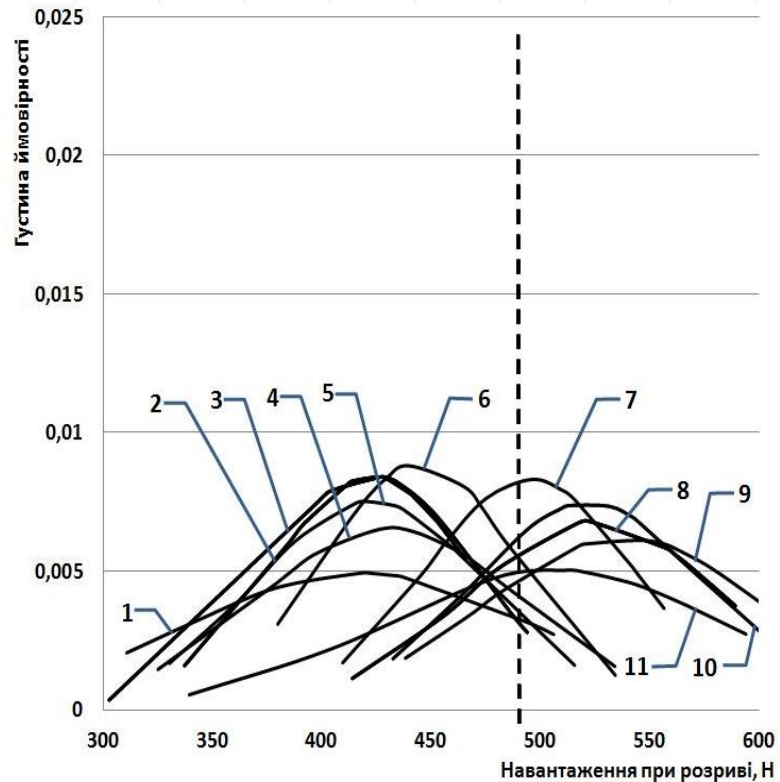

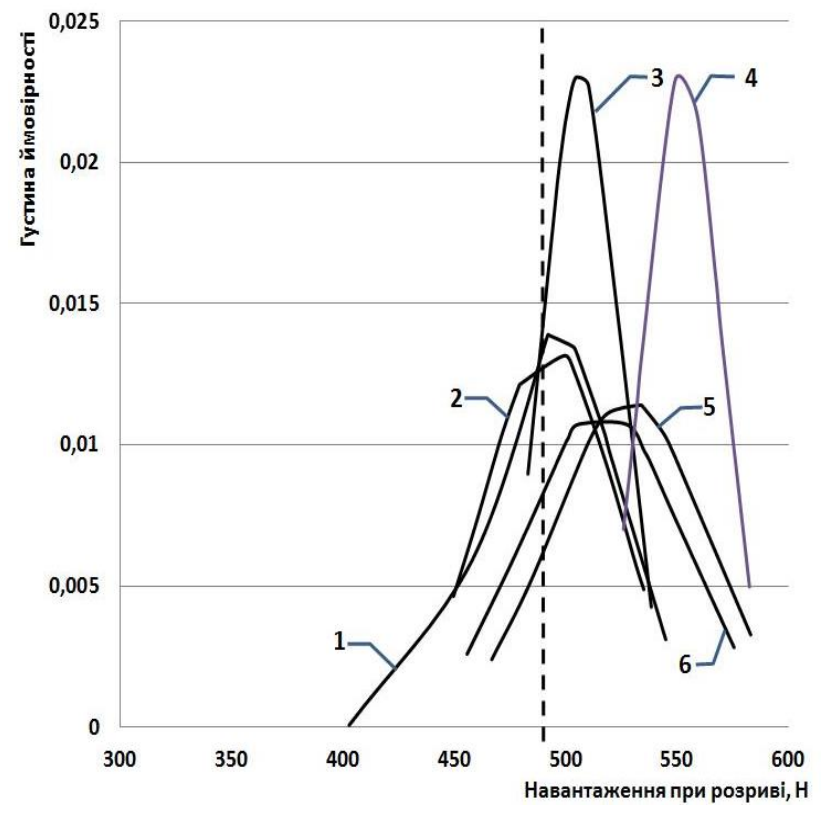

6

Рис. 2. Графік залежності густини ймовірності від навантаження при розриві по основі тканини куполу основного парашута (1974 рік виготовлення):

позначення на рис. 2 а: 1 - парашутна система № 7442112; 2 - № 7436617; 3 - № 7438208; 4 - № 7403408; 5 - № 7437601; 6 - № 7437514; 7 - № 7409914; 8 - № 7411015; 9 - № 7414021;

$$
10 \text { - № 7459703; } 11 \text { - № 7414423; }
$$

позначення на рис. 2 б: 1 - парашутна система № 7460413; 2 - № 7441012; 3 - № 7403508; 4 - № 7403704;

$$
5 \text { - № } 7402819 ; 6 \text { - № } 7414414
$$

Джерело: розроблено авторами за даними [2].

Для зручності сприйняття на поле рисунків нанесена пунктирна вертикальна лінія, що позначає межу, яка відповідає мінімальному необхідному номінальному значенню розривного навантаження смуги тканини артикул 56009П. Ця величина стано- вить $490 \mathrm{H}$.

На основі первинних даних були обраховані статистичні характеристики, які наведені у табл. 1 для парашутів 1973 року виготовлення і табл. 2 для парашутів 1974 року виготовлення.

Таблиця 1

Статистичні характеристики результатів вимірювання значення розривного навантаження

\begin{tabular}{|c|c|c|c|c|c|c|c|}
\hline $\begin{array}{l}\text { № } \\
\text { 3/ח }\end{array}$ & $\begin{array}{c}\text { Десантна } \\
\text { парашутна } \\
\text { система Д-5 серіï } 2 \\
\end{array}$ & № в/ч & $\begin{array}{c}\text { Середнє } \\
\text { значення, Н }\end{array}$ & $\begin{array}{c}\text { Невизначеність, } \\
\pm \mathrm{H}\end{array}$ & $\begin{array}{c}\text { Дисперсія } \\
\text { вибірки, }(\mathrm{H})^{2}\end{array}$ & Ексцес & Медіана, Н \\
\hline 1 & № 7306722 & \multirow{5}{*}{ A 0281} & 510,1 & 18,8 & 690,9 & $-1,3$ & 506,7 \\
\hline 2 & № 7307212 & & 499,2 & 21,7 & 921,9 & $-0,7$ & 497,6 \\
\hline 3 & № 7317206 & & 517,4 & 15,1 & 444,5 & $-0,1$ & 517,3 \\
\hline 4 & № 7318807 & & 491,4 & 34,4 & 2307,3 & $-1,0$ & 501,1 \\
\hline 5 & № 7320301 & & 532,2 & 11,9 & 239,0 & $-0,9$ & 524,2 \\
\hline \multicolumn{3}{|c|}{ Середнє значення за партію } & 510,1 & 20,4 & 920,7 & - & - \\
\hline 6 & № 7329301 & \multirow{2}{*}{ A0224 } & 461,9 & 17,2 & 656,4 & $-1,1$ & 469,9 \\
\hline 7 & № 7329215 & & 497,2 & 24,0 & 825,9 & $-0,1$ & 498,1 \\
\hline \multicolumn{3}{|c|}{ Середнє значення за партію } & 479,6 & 20,6 & 741,2 & - & - \\
\hline 8 & № 7320110 & A2120 & 523,4 & 17,8 & 536,6 & $-1,5$ & 522,9 \\
\hline \multicolumn{3}{|c|}{ Середнє значення за партію } & 523,4 & 17,8 & 536,6 & - & - \\
\hline \multicolumn{3}{|c|}{$\begin{array}{c}\text { Середнє значення за партію за рік } \\
\text { виготовлення }\end{array}$} & 504,3 & 19,6 & 732,8 & - & - \\
\hline
\end{tabular}
по основі тканини куполу основного парашуту 1973 року виготовлення

Джерело: розроблено авторами. 
Статистичні характеристики результатів вимірювання значення розривного навантаження по основі тканини куполу основного парашуту 1974 року виготовлення

\begin{tabular}{|c|c|c|c|c|c|c|c|}
\hline $\begin{array}{l}\text { № } \\
3 / \Pi\end{array}$ & $\begin{array}{c}\text { Десантна } \\
\text { парашутна } \\
\text { система Д-5 } \\
\text { серії } 2\end{array}$ & № В/ч & $\begin{array}{c}\text { Середнє } \\
\text { значення, Н }\end{array}$ & $\begin{array}{c}\text { Невизначеність, } \\
\pm \mathrm{H}\end{array}$ & $\begin{array}{c}\text { Дисперсія } \\
\text { вибірки, }(\mathrm{H})^{2}\end{array}$ & Ексцес & Медіана, Н \\
\hline 1 & № 7414414 & \multirow{4}{*}{ A0281 } & 516,4 & 25,4 & 1258,2 & $-0,2$ & 516,4 \\
\hline 2 & № 7403508 & & 506,6 & 14,4 & 297,5 & 0,6 & 502,4 \\
\hline 3 & № 7402819 & & 528,0 & 24,8 & 1197,8 & $-0,1$ & 534,1 \\
\hline 4 & № 7414423 & & 506,4 & 56,6 & 6260,2 & 1,1 & 530,4 \\
\hline \multicolumn{3}{|c|}{ Середнє значення за партію } & 514,4 & 30,3 & 2253,4 & - & - \\
\hline 5 & № 7403408 & \multirow{2}{*}{ A0224 } & 430,8 & 43,7 & 3736,8 & $-0,2$ & 434,6 \\
\hline 6 & № 7403704 & & 552,3 & 17,1 & 420,2 & $-1,5$ & 553,8 \\
\hline \multicolumn{3}{|c|}{ Середнє значення за партію } & 491,6 & 30,4 & 2078,5 & - & - \\
\hline 7 & № 7459703 & \multirow{4}{*}{ A2120 } & 552,0 & 38,2 & 2857,9 & 0,5 & 522,7 \\
\hline 8 & № 7460413 & & 495,3 & 28,5 & 1581,7 & 2,9 & 504,0 \\
\hline 9 & № 7414021 & & 538,0 & 46,0 & 4137,1 & $-1,1$ & 535,5 \\
\hline 10 & № 7411015 & & 525,2 & 42,1 & 3457,8 & $-0,4$ & 540,4 \\
\hline \multicolumn{3}{|c|}{ Середнє значення за партію } & 527,6 & 38,7 & 3008,6 & - & - \\
\hline 11 & № 7441012 & \multirow{6}{*}{ A1126 } & 492,7 & 21,2 & 877,1 & $-1,3$ & 489,2 \\
\hline 12 & № 7436617 & & 423,6 & 33,9 & 2249,9 & 0,0 & 420,6 \\
\hline 13 & № 7437601 & & 422,3 & 38,0 & 2824,7 & 0,2 & 426,6 \\
\hline 14 & № 7442112 & & 417,7 & 43,6 & 3712,4 & $-0,2$ & 427,9 \\
\hline 15 & № 7438208 & & 421,3 & 33,7 & 2215,8 & 4,8 & 435,1 \\
\hline 16 & № 7437514 & & 445,1 & 32,2 & 2025,9 & 0,4 & 434,5 \\
\hline \multicolumn{3}{|c|}{ Середнє значення за партію } & 437,1 & 33,8 & 2317,6 & - & - \\
\hline 17 & № 7409914 & A0284 & 495,1 & 34.3 & 2304,5 & $-0,7$ & 503,1 \\
\hline \multicolumn{3}{|c|}{ Середнє значення за партію } & 495,1 & 34,3 & 2304,5 & - & - \\
\hline \multicolumn{3}{|c|}{$\begin{array}{c}\text { Середнє значення за партію за } \\
\text { рік виготовлення }\end{array}$} & 493,1 & 33,5 & 2392,5 & - & - \\
\hline
\end{tabular}

Джерело: розроблено авторами.

3 огляду на розміщення кривих розподілу ймовірності на рис. 1-2 можна відмітити характерні особливості.

По-перше, максимальні значення густини ймовірності для вибірок парашутів 1973 року виготовлення (рис. 1) вищі за значення вибірок для парашутів 1974 року виготовлення (рис. 2). Такий стан пояснюється обов'язковими процедурами статистичної обробки результатів, на рис. 136 наведених 3 вибірки були скорочені за рахунок наявності грубих помилок. Це збільшило густину ймовірності. 311 вибірок для парашутів 1974 року виготовлення (рис. 2) тільки 2 вибірки мали грубі помилки, на рис. 2 б вони позначені цифрами 3 та 4. Слід відзначити, що відкидалися переважно мінімальні значення розривного навантаження.

По-друге, на рис. 1 це не так явно видно за рахунок невеликої кількості вибірок, проте на рис. 2 можна виділити 4 групи: криві $(1-6$; рис. 2a), (7 - 11; рис. 2 a) $(1,2,5,6$; рис. 26$)$ та $(3,4$; рис. 26$)$ відповідно. До складу групи 1 увійшли переважно парашути, що зберігалися на складах у військовій частині A1126, групу 2 утворили переважно пара- шути 3 військової частини А2120, у групах 3 та 4 половина парашутів зберігалась у військовій частині А0281. 3 таким розподілом, 3 одного боку, можна стверджувати, що умови зберігання у військовій частині А1126 були найгірші (низькі значення розривного навантаження), 3 іншого боку, це можна пояснити відмінностями у підготовці зразків і самої процедури вимірювання. Якщо взяти до уваги, що організаційно парашути досліджувалися партіями 3 військових частин це можливо, тому на майбутнє слід переходити на метод сліпого вибору.

Середня вибірки вважається “доброю” (незміщеною та ефективною) оцінкою математичного очікування випадкової величини. Середнє значення навантаження при розриві тканини куполів парашутів різних років виготовлення значно відрізняються (табл. 1-2). Різниця у часі виготовлення занадто мала у порівнянні з часом зберігання, тому найбільш ймовірним поясненням будуть значні відмінності в умовах зберігання та у підходах до регламентних робіт під час обслуговування у військових частинах. Слід взяти до уваги, що незважаючи на достатній загальний середній рівень навантаження при розриві 
тканини куполу парашуту, наявні аномально низькі значення цього показника для парашутів, що зберігаються в окремій військовій частині (табл. 2, частини A1126). На нашу думку, таке зниження не можна пояснити аномальним перебігом процесів природного старіння полімеру.

Значення медіани, зазвичай, краще ніж середнє значення відображає центральне значення. За цим показником навантаження при розриві строп (табл. 1) вибірки зміщені як у бік менших значень (5 випадки), так і у бік більших значень (3 випадки). Для парашутів 1974 року виготовлення (табл. 2) вибірки у 5 випадках з 17 зміщені у бік менших значень, це свідчить про відсутність стійкої тенденції на зменшення показника міцності матеріалу купола парашуту.

Ексцес відображає відносну складову частин вибірки відносно ії центральної частини, тобто вказує на більшу або меншу “концентрацію” значень показника в околі його очікуваного (середнього) значення. Для парашутів 1973 року виготовлення (табл. 1) коефіцієнти ексцесу мають виключно негативні значення на відміну від даних для парашутів 1974 року виготовлення, (табл. 2), де вони мають позитивні і негативні значення. За партіями парашутів (місцями зберігання) такої кореляції не виявлено, але це вказує можливі зміни у самому процесі вимірювання.

Дисперсія і невизначеність пов'язані між собою математично, тому немає сенсу обговорювати їх окремо. Невизначеність (похибка) вимірювань навантаження при розриві для парашутів 1973 року виготовлення коливається у незначних межах (табл. 1) і має прийнятне середнє значення. Для парашутів 1974 року виготовлення (табл. 2) коливання теж незначні, але по окремих партіях різниця між максимальним і мінімальним значенням складає до 4 разів.

Загальний рівень невизначеності видовження при розтяганні строп за даними табл. 2 (1973 рік виготовлення) значно (в 1,7 рази) нижчий по відношенню до парашутів 1974 року виготовлення, і вони менш розпорошені у партіях парашутів. Це вказує на можливі зміни метрологічного характеру у процесі вимірювання, що негативно вплинуло на якість результатів.

Відносна похибка результатів вимірювання навантаження при розриві тканини по основі куполів парашутів 1973 року виготовлення склала $\pm 3,9 \%$, для парашутів 1974 року виготовлення - $\pm 6,8 \%$. 3 урахуванням того, що прилад для вимірювання має похибку $\pm 0,29$ \% за паспортом, яку можна вважати систематичною, переважний внесок у величину невизначеності мають похибки при організації самого процесу вимірювань. 3 іншого боку загальний рівень невизначеності $є$ прийнятним для звичайних вимірювань у техніці.

\section{Висновки}

1. На результат і якість вимірювання навантаження при розриві тканини по основі куполу парашуту основного вплинули умови зберігання у війкових частинах та особливості організації та проведення вимірювань. Переважними слід вважати чинники метрологічного характеру.

2. Для планування величини партії парашутних систем в аналогічних роботах по визначенню навантаження при розриві тканини куполу парашуту основного артикул 56009П за ГОСТ 13090-90 невизначеність приймати $\pm 5,0 \%$.

\section{Список літератури}

1. Сила I. М., Королев О. О., Кучинський А. В. Формування удосконаленого методичного апарату проведення лабораторних досліджень (випробувань) зразків парашутної техніки. Збірник наукових праць Центрального науководослідного інституту озброєння та військової техніки Збройних Сил України. 2021. № 3. С. 27-30.

2. Дослідження шляхів визначення можливості збільшення призначених показників повітрянодесантної техніки підрозділів (військових частин) Збройних Сил України, які використовують парашутне десантування [Текст] : Звіт про НДР (заключн.) / Держ. наук.-дослідн. ін-т. випробувань і сертифікації озброєння та військової техніки; кер. Корольов О. О.; викон. Сила І. М. та ін. Чернігів, 2019. 180 с. № ДР 19015-027.

3. Фомичев П. А. Установление ограничений по максимальным скоростям десантирования с учетом деградации прочностных характеристик материалов купола парашюта. Сообщение 1. Зависимость прочности парашютов от деградации прочностных характеристик конструкционных материалов. Авиационно-космическая техника и технология. 2019. № 1(153). C. 65-71.

4. Фомичев П. А. Установление ограничений по максимальным скоростям десантирования с учетом деградации прочностных характеристик материалов купола парашюта. Сообщение 2. Зависимость максимальных скоростей десантирования от деградации прочности. Авиационно-космическая техника и технология. 2019. № 2(154). С. 61-68. https://doi.org/10.32620/ aktt.2019.2.08.

5. Фомичев П. А., Сила И. М. Закон распределения разрушающих нагрузок элементов каркаса купола парашюта. Авиационно-космическая техника и технология. 2019. № 4(156). С. 73-79. https://doi.org/10.32620/aktt.2019.4.12

6. Теоретико-експериментальне визначення залишкової міцності текстильних елементів конструкцій авіаційнорятувальних систем з метою продовження термінів їх експлуатації. Розробка методів і засобів випробувань на міцність тканинних елементів авіаційних конструкцій. Проведення випробувань на міцність [Текст] : Звіт про НДР (проміжн.) / Національний аерокосмічний університет ім. М. С. Жуковського “Харківський авіаційний інститут”; кер. Фомичов П. О.; викон. Кучерявий Є. Ф. [та ін.]. Харків, 2018. 218 с. № ДР 0118Ш003821. 
7. Сила I. М. Експериментальне визначення стану текстильних матеріалів десантної парашутної системи д-5 серії 2 після тривалого зберігання. Повідомлення 1. Фактичний стан міцності текстильних матеріалів основного парашуту. Авiаційно-космічна техніка і технологія. 2021. № 2(170). C. 4-11. https://doi.org/10.32620/aktt.2021.2.01.

8. Лобанов Н. А. Основы расчета и конструирования парашютов. Москва : Машиностроение, 1965. $363 \mathrm{c.}$

9. Гмурман В. Е. Теория вероятности и математическая статистика: учеб. пособ. для вузов. Москва : Высшая школа, 2004. 479 с.

10. Ломакина И. А., Грузинцева Н. А., Гусев Б. Н. Определение нормативных значений по разрывной нагрузке ткани с использованием статистических характеристик. Технология текстильной промышленности. 2009. № 3(316). C. $8-10$.

\section{Відомості про авторів:}

\section{Корольов Олександр Олександрович}

кандидат технічних наук доцент провідний науковий співробітник

Державного науково-дослідного інституту випробувань і сертифікації озброєння і військової техніки,

Чернігів, Україна

https://orcid.org/0000-0002-1098-2007

\section{Сила Ігор Михайлович}

начальник науково-дослідного відділу

Державного науково-дослідного інституту випробувань і сертифікації озброєння і військової техніки,

Чернігів, Україна,

https://orcid.org/0000-0002-8029-6598

\section{Сиза Ольга Іллівна}

доктор технічних наук професор

професор кафедри

Національного університету

"Чернігівський колегіум" ім. Т.Г. Шевченка,

Чернігів, Україна,

https://orcid.org/ 0000-0003-4624-9656

\section{Гейко Вадим Васильович}

начальник науково-дослідної лабораторії

Державного науково-дослідного інституту випробувань

і сертифікації озброєння і військової техніки,

Чернігів, Україна

https://orcid.org/0000-0003-0981-5794

\section{Information about the authors:}

\section{Oleksandr Korolyov}

$\mathrm{PhD}$ in Engineering Associate Professor

Leading Researcher

of the State Research Institute for Testing and Certification of Weapons and Military Equipment,

Chernihiv, Ukraine,

https://orcid.org/0000-0002-1098-2007

\section{Ihor Syla}

Head of the Research Department

of the State Research Institute for Testing and Certification of Weapons and Military Equipment, Chernihiv, Ukraine, https://orcid.org/0000-0002-8029-6598

\section{Olga Sizaya}

Doctor of Engineering Science Professor

Professor of Department

of the T.H. Shevchenko National University

"Chernihiv Colehium",

Chernihiv, Ukraine

https://orcid.org/ 0000-0003-4624-9656

\section{Vadym Heiko}

Head of the Research Laboratory

of the State Research Institute for Testing and Certification of Weapons and Military Equipment, Chernihiv, Ukraine, https://orcid.org/0000-0003-0981-5794

\title{
ЭКСПЕРИМЕНТАЛЬНОЕ ОПРЕДЕЛЕНИЕ СОСТОЯНИЯ МАТЕРИАЛОВ ПАРАШЮТНОЙ СИСТЕМЫ Д-5 СЕРИИ 2. СТАТИСТИЧЕСКИЕ ХАРАКТЕРИСТИКИ ПРОЧНОСТИ ТКАНИ ОСНОВНОГО ПАРАШЮТА
}

\author{
А.А. Королев, И.М. Сила, О.И. Сизая, В.В. Гейко
}

Предметом изучения в статье является анализ массива экспериментальных данных нагрузки при разрыве ткани по основе купола парашюта основного десантных парашютных систем Д-5 серий 21973 и 1974 годов изготовления после них длительного хранения с нулевым (неисчерпанным) ресурсом. Целью статьи является попьтка на основе статистического анализа результатов измерений определить соотношение влияния внешних факторов, связанньх с естественными факторами старения полимеров и условиями хранения, и внутренних, что обусловлень погрешностями в процессе измерения. Задание: определить оптимальный перечень данных статистического анализа результатов измерения для оченки качества проиесса измерения. Использовались следуюшие методы и оборудование. Усовершенствованная методика отбора точечных проб исследуемых образиов десантных парашютных систем Д-5 серий 2 для проведения лабораторных исследований по определению нагрузки при разрыве ткани купола парашюту основного. Измерения проводились на машине разрывной марки ИР 5047-50М2С, класс точности - 0,5 для диапазона измерений от 0,5 кН до 5 кН. Объем партии составил 25 парашютных систем, всего 250 элементарных проб. Массив эмпирических данных был обработан математико-статистическими методами пакета программ Описательная статистика из надстройки Пакета Анализа MS EXCEL. Полученные следуюшие результаты. Относительная погрешность результатов измерения нагрузки при разрыве ткани по основе куполов парашютов 1973 года изготовления составляет $\pm 3,9 \%$, для парашютов 1974 года изготовления - $\pm 6,8 \%$. С учетом того, что прибор для измерения имеет погрешность $\pm 0,29 \%$ по паспорту, которую можно считать систематической, общий уровень неопределенности является приемлемым для обычных измерений в технике. Выводы. Основными факторами появления случайных погрешностей в прочессе измерения нагрузки при разрыве ткани купола по основе парашюта основного являются внутренние факторы, обусловленные организацией и проведением измерений.

Ключевые слова: ткань, статистика, анализ, парашют. 


\title{
EXPERIMENTAL DETERMINATION OF THE STATE OF MATERIALS OF PARACHUTE SYSTEM Д-5 SERIES 2. STATISTICAL DESCRIPTIONS OF DURABILITY OF FABRIC OF BASIC PARACHUTE
}

\author{
O. Korolev, I. Syla, O. Sizaya, V. Heiko
}

The article of study in the article is an analysis of array of experimental data of loading at the break of fabric warpwise canopy basic landings parachute systems of Д-5 cerouss 21973 and 1974 making after them the protracted storage with a zero (inexhausted) resource. The aim of the article is an attempt on the basis of statistical analysis of results of measuring to define correlation of influence of external factors, related to the natural factors of senescence of polymers and terms of storage, and internal, that conditioned by errors in the process of measuring. Task: to define the optimal list of data of statistical analysis of results of measuring for the estimation of quality of measuring process. Next methods and equipment were used. Improved methodology of selection of point tests of the investigated standards of the landings parachute systems of Д-5 cerouss 2 for realization of laboratory researches on determination of loading at the break of fabric warpwise of dome to the parachute of basic. Measuring was conducted on the machine of break brand of ИР 5047-50M2C, class of exactness - 0,5 for the range of measuring from $0,5 \mathrm{\kappa H}$ to $5 \mathrm{kH}$. The volume of party made 25 parachute systems, only 250 elementary tests. The array of empiric data was treated by the by mathematical and statistical methods of package of softwares Descriptive statistics from building on of Package of Analysis of MS EXCEL. Got next results. A relative error of results of measuring of loading at the break of fabric warpwise domes of parachutes of 1973 of making is $\pm 3,9 \%$, for the parachutes of 1974 of making $- \pm 6,8 \%$. Taking to account that a device for measuring has an error $\pm 0,29 \%$ on a passport, which can be considered systematic, a general level of vagueness is acceptable to the ordinary measuring in a technique. Conclusions. The result and quality of measurement of the load at the rupture of the fabric on the basis of the dome of the main parachute was influenced by storage conditions in the ciliary parts and features of the organization and conduct of measurements. Metrological factors should be considered predominant.

Keywords: fabric, statistics, analysis, parachute. 